Омербаев Исатай Кайратулы, Магистрант Павлодарский Государственный Университет имени С. Торайгырова

г. Павлодар, Казахстан. E-mail: Omerbayev@mail.ru ORCID ID 0000-0002-0936-2492

\title{
РАЗРАБОТКА СПОСОБА ИЗВЛЕЧЕНИЯ ВАНАДИЯ И НИКЕЛЯ ИЗ ТЯЖЕЛЫХ НЕФТЯНЫХ ОСТАТКОВ
}

Omerbayev Issatay Kairatuly, Master student S. Toraigyrov Pavlodar State University City Pavlodar, the Republic of Kazakhstan

E-mail: Omerbayev@mail.ru ORCID ID 0000-0002-0936-2492

\section{DEVELOPMENT OF A METHOD FOR EXTRACTING VANADIUM AND NICKEL FROM HEAVY OIL RESIDUES}

Annotation: Prospects of improving refining with simultaneous extraction of metal impurities (vanadium, nickel). The analysis of the different ways demetallisation. To remove metals from used oil extraction-settling, adsorption and adsorption-catalytic, hydrogenation, thermal, chemical and other nontraditional ways. The structure of the porphyrin metal complexes in the oil. The most promising method for the isolation of metalloporphyrins of oil is a selective extraction of polar solvents. Developed methods for the removal of metals using magnetic properties.

On a number of refineries used a catalytic hydrotreating catalysts for three-phase reactor. The main directions of further work on demetallisation oil.

Keywords: heavy oil residues, demetallisation, vanadium, nickel, metalloporphyrins, selective extraction, catalytic hydrotreating.

Аннотация: В данной статье представлены перспективы извлечения металлов-примесей (ванадия, никеля) из тяжелых нефтяных остатков благодаря усовершенствованию методов переработки нефти. Дан анализ различных способов деметаллизачии. Для удаления металлов из нефти используются экстракиионно-осадительные, адсорбционные и адсорбиионнокаталитические, гидрогенизачионные, термические, химические и другие нетрадичионные способы. Рассмотрена структура порфириновых комплексов металлов в нефти. Наиболее перспективный метод выделения металлопорфиринов из нефти - это селективная экстракция их полярными растворителями. Разрабатываются способы удаления металлов с использованием магнитных свойств.

На ряде нефтеперерабатывающих предприятий применяется способ каталитической гидроочистки в трехфазном реакторе. Определены основные направления дальнейшей работы по деметаллизации нефти.

Ключевые слова: тяжелье нефтяные остатки, деметаллизация, ванадий, никель, металлопорфирины, селективная экстракиия, каталитическая гидроочистка.

В нефтях, как известно, обнаружено более 60 различных микроэлементов и металлов, концентрация которых изменяется в очень широких пределах: от следов до сотен граммов на тонну нефти. Повышенное содержание микроэлементов металлов, как правило, характерно для высоковязких тяжелых нефтей и природных битумов.

Рассмотрен ресурсный потенциал тяжелых нефтей Республики Казахстан. Значительный потенциал тяжелых нефтей осваивается в нашей стране недостаточно, а

Разработка способа извлечения ванадия и никеля
Материалы Международной практической интернет-конференции «Актуальные Проблемы Науки» 
возможность извлечения ценных попутных компонентов из них, соединений ванадия и никеля, в частности, практически пренебрегается, что является крайне актуальной задачей в настоящее время при вынужденном переходе к широкомасштабному освоению ресурсов тяжелых нефтей.

Вместе с тем, практика показывает, что при существующих технологических схемах переработки нефти теряется большое количество попутно-добываемых с нефтью полезных компонентов (золота, цинка, меди, никеля, ванадия и др.). Это приводит так же к снижению качества нефти, нежелательных экологических смещений природного равновесия при попадании металлов в продукты переработки нефти. В этой связи поиск инновационных схем подготовки и переработки нефти с извлечением попутнодобываемых металлов является актуальной научной проблемой современной нефтегазовой отрасли и, в частности, нефтеперерабатывающих заводов (НПЗ). Кроме того, отпускная цена на нефть не учитывает стоимость содержащихся в нефти металлов, в связи с отсутствием технологии извлечения металлов из нефти, что наносит большие убытки для нефтегазовой отрасли страны в целом.

Установлено, что в тяжелых нефтях и битумах присутствуют в большом количестве редкие металлы - ванадий и никель. Ванадий используют в военной и металлургической промышленности, животноводстве, в медицине и в других областях [1].

Исследования нефти Казахстана показало, что ванадий присутствуют почти во всех месторождениях нефти.

Таким образом, проблемы извлечения металлов из нефти, в частности разработка эффективного метода извлечения соединений ванадия и никеля весьма актуальны в нефтяной отрасли.

Металлы в нефти в основном находятся в форме солей органических кислот типа $\mathrm{R}-\mathrm{COOH}$ или хелатных комплексов. Порфирины представляют собой соединения, в которых четыре пиррольных кольца соединены метановыми мостиками в единую циклическую сопряженную систему в основе которой лежит 16-членный макроцикл, включающий 4 атома азота. Родоначальник и простейший представитель порфиринов порфин. В качестве заместителя могут выступать радикалы предельных и непредельных углеводородов, кислот, сложных эфиров, альдегидов, ароматических соединений и т.д. Эти порфирины называются свободными порфириновыми основаниями и в природе встречаются довольно редко [1].
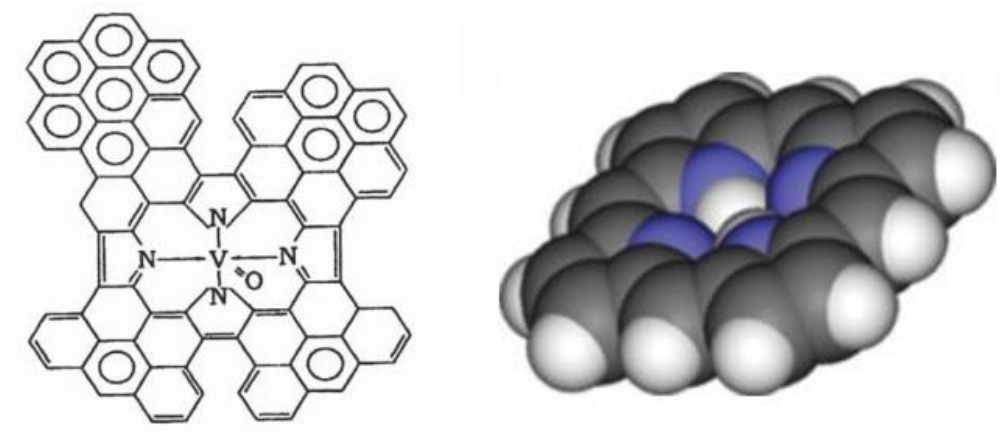

Рисунок 1 - Структура порфириновых комплексов ванадия в нефти [1]

Первая группа методов выделения порфиринов из нефти, применяемая и в настоящее время, основана на обработке нефти и нефтяных компонентов сильными кислотами. При использовании кислот с целью выделения нефтяных порфиринов

Разработка способа извлечения ванадия и никеля
Материалы Международной практической интернет-конференции «Актуальные Проблемы Науки» 
происходит деметаллирование металлопорфиринов с дальнейшим их переходом в кислотную фазу.

В качестве деметаллирующих агентов используются такие кислоты, как уксусная и муравьиная, насыщенные бромистым водородом, сульфокислоты, серная и фосфорная кислоты [1]. Для деметаллизации всей массы порфиринов нефти используют обычно бромистый водород, растворенный в уксусной кислоте. Однако технические трудности не позволяют проводить массовые эксперименты. Обработка соляной кислотой не приводит к образованию свободных порфириновых оснований. Деметаллизация фосфорной кислотой требует довольно высокой температуры $\left(180{ }^{\circ} \mathrm{C}\right)[3]$.

Установлено, что наилучшие результаты достигаются при деметаллизации концентрата нефтяных металлопорфиринов с помощью концентрированной серной кислоты. Деметаллирование происходит при пониженной температуре $\left(13-15{ }^{\circ} \mathrm{C}\right)$ за $3-5$ минут. Лишь небольшая часть металлопорфиринов остается в виде металлокомплексов, а основная масса (80-90 \%) превращается в свободные основания. Разрушение свободных порфириновых оснований за короткое время контакта с кислотой ничтожно. На основе реакции серной кислоты с синтетическими ванадил-, никель- и медными этиопорфиринами, авторы работы пришли к выводу, что серная кислота является наиболее мягким из известных деметаллирующих реагентов. Однако, для нефтяных порфиринов это не совсем верно, так как при длительном контакте с кислотой происходит их разрушение. По аналогии с другими реакциями общую схему взаимодействия металлопорфиринов с серной кислотой можно представить следующим образом [3]:

$$
\text { PorM }+\mathrm{H}_{2} \mathrm{SO}_{4}=\mathrm{PorH}_{2}+\mathrm{MSO}_{4} \text {, }
$$

где PorM - ванадил или никельпорфирин; $\mathrm{PorH}_{2}$ - свободное основание порфирина.

Образование свободного основания порфиринов проходит через дикатионы. Недостатком выделения нефтяных порфиринов с помощью кислот является частичная деструкция порфиринов (40-80 \%), а также невозможность раздельного определения содержания и исследования металлопорфириновых комплексов ванадила и никеля. Также кислотная экстракция плохо применима к нефтям с невысокой концентрацией порфиринов. Преимуществами экстракции порфиринов кислотной являются малая трудоемкость, а также возможность получать сразу относительно чистые концентраты порфириновых соединений.

К второй группе относятся методы экстракции металлопорфиринов несмешивающимися с нефтью растворителями с дальнейшей очисткой экстракта. Преимуществом экстракционных методов с использованием селективных растворителей являются мягкие условия процесса, что полностью исключает возможность каких-либо химических превращений. В качестве растворителей, используемых для экстракции металлопорфиринов, применяются этиловый спирт, ацетонитрил и N,N-диметилформамид (ДМФА) [4]. При сравнении селективности и степени извлечения металлопорфиринов этими растворителями установлено, что ДМФА наиболее полно извлекает металлопорфирины, причем при его использовании экстрагируются все металлопорфирины, в то время как ацетон и спирты экстрагируют в основном их наиболее полярную часть. Несколько патентов описывают экстракцию ванадилпорфиринов 2 пирроллидоном и бутиролактоном [5]. Однако данные, описанные в этих патентах, получены для нефтей с низким содержанием ванадилпорфиринов и асфальтенов. Для легких нефтей со сравнительно невысоким содержанием асфальтено-смолистых веществ

Разработка способа извлечения ванадия и никеля
Материалы Международной практической интернет-конференции «Актуальные Проблемы Науки» 
для экстракции нефтяных порфиринов наиболее всего подходит третья группа методов выделения - комплексообразование с кислотами Льюиса, в качестве которых чаще всего используются безводные галогениды металлов. Сущность метода заключается в образовании нерастворимых в углеводородных системах молекулярных комплексов нефтяных металлопорфиринов с галогенидами титана или железа, с последующим выделением этих комплексов, разрушением и регенерацией металлопорфиринов. Преимуществом этого метода является возможность полного выделения металлопорфиринов при содержании их в следовых концентрациях [5].

Деметаллизация тяжелого нефтяного сырья, как правило, рассматривается в рамках общих подходов к подготовке (облагораживанию) и переработке тяжелых нефтей, обеспечивающих улучшение качества и/или эффективное использование органической части нефтяного сырья. В этой связи концентрирование металлов из ТНС в различной степени может достигаться в результате как деструктивных термических и термокаталитических процессов его конверсии, так и недеструктивных массообменных процессов.

К основным достоинствам термических процессов переработки тяжелых нефтяных остатков следует отнести меньшие, по сравнению с каталитическими процессами, капитальные вложения и эксплуатационные затраты, а также их сырьевую всеядность, прежде всего по отношению к коксуемости и содержанию металлов перерабатываемого сырья. Главный их недостаток заключается в низком качестве получаемых жидких продуктов.

Значительно более высокие выход и качество дистиллятных продуктов достигаются в каталитических и гидрокаталитических процессах. Гидрогенизационные каталитические процессы позволяют за счет деметаллизации, удаления гетероатомных соединений и насыщения водородом облагораживать тяжелое нефтяное сырье и получать при этом товарные моторные топлива или высококачественное сырье для дальнейшей переработки. Однако данным процессам присущи значительные как капитальные, так и эксплуатационные затраты, связанные с большим расходом катализатора и водорода.

На сегодняшний день общая тенденция развития наиболее перспективных способов и технологий деметаллизации нефтей и концентрирования ценных металлов связана с одной стороны с созданием процессов их выделения из углеводородного сырья на более ранних стадиях нефтепереработки, а с другой с существенным снижением выхода металлсодержащих остатков путем реализации процессов суспензионной гидроконверсии, термоконтактного крекинга с непрерывным сжиганием или газификацией кокса и экстракции растворителями в сверхкритическихусловиях.

В результате реализации описанных технологий деметаллизации ТНС представляется возможным не только производство концентратов редких металлов, но и попутное существенное улучшение качества товарных нефтей и сырья для получения наиболее ценных нефтепродуктов.

\section{ЛИТЕРАТУРА}

1. Danilova E. Demetallization of oil residues. // The Chemical Journal. - 2008. V. 53. N 4. P. 34.

2. Banerjee D. K. Oil Sands, Heavy Oil \& Bitumen // From Recovery to Refinery: Penn Well. XVII. 2012. - V. 17. N 5. - P. 185.

3. Ахметов А.Ф., Красильникова Ю.В. Комплексное освоение тяжелых нефтей. //Башкирский химический журнал. - 2011. - Т. 18. - № 2. - С. 93.

Разработка способа извлечения ванадия и никеля
Материалы Международной практической интернет-конференции «Актуальные Проблемы Науки» 
4. Надиров Н.К., Котова А.В., Камьянов В.Ф. Новые нефти Казахстана и их использование. - Алматы: Наука, 1984. - С. 448.

5. Шпирт М.Я., Нукенов Д.Н., Пунанова С.А. Сравнительная оценка микроэлементного состава углей, сланцев и нефтей. // Химия твердого топлива. - 2007. - № 5. - С. 15.

\section{REFERENCES}

1. Danilova E. Demetallization of oil residues. The Chemical Journal. 2008. 34 (in Eng.).

2. Banerjee D. K. Oil Sands, Heavy Oil \& Bitumen. From Recovery to Refinery: Penn Well. XVII. 2012, 185 (in Eng.).

3. Akhmetov A.P., Krasylnikova Yu.V. Kompleksnoye osvoyenie tyazhelykh neftey (Complex development of heavy oils). Bashkirskiy khimicheskiy zhurnal = Bashkirian chemical journal . 2011. 2, 93 (in Russ.).

4. Nadirov N.K., Kotova A.V., Kamyanov V.P. Novyye nefti Kazakhstana i ikh ispol'zovaniye (New Kazakhstan's oil and their use). Almaty. 1984, 448 (in Russ.).

5. Shpirt M.Ya., Nukenov D.N., Punanova S.A. Sravnitel'naya otsenka mikroelementnogo sostava ugley, slantsev i neftey (Comparative evaluation of the trace element composition of coal, shale and oil). Khimiya tverdogo topliva $=$ Chemistry of solid fuels. 2007. 5, 15 (in Russ.). 